\title{
Effects of Bacterial Organic Selenium, Selenium Yeast and Sodium Selenite on Antioxidant Enzymes Activity, Serum Biochemical Parameters, and Selenium Concentration in Lohman Brown-Classic Hens
}

\section{A. I. Muhammad}

Federal University Dutse

A. M. Dalia

University of Khartoum

T. C. Loh

Universiti Putra Malaysia

H. Akit

Universiti Putra Malaysia

A. A. Samsudin ( $\sim$ anjas@upm.edu.my )

Universiti Putra Malaysia

\section{Research Article}

Keywords: Antioxidant enzymes, Bacterial organic selenium, Serum biochemical parameters, Selenium concentrations

Posted Date: September 29th, 2021

DOI: https://doi.org/10.21203/rs.3.rs-872160/v1

License: @ (i) This work is licensed under a Creative Commons Attribution 4.0 International License. Read Full License

Version of Record: A version of this preprint was published at Veterinary Research Communications on November 30th, 2021. See the published version at https://doi.org/10.1007/s11259-021-09867-3. 


\section{Abstract}

This study compares the effects of sodium selenite, selenium yeast, and enriched bacterial organic selenium protein on antioxidant enzyme activity, serum biochemical profiles, and egg yolk, serum, and tissue selenium concentration in laying hens. In a 112-d experiment, 144 Lohman Brown Classic hens, 23wks old were divided into four equal groups, each has six replicates. They were assigned to 4 treatments: 1) a basal diet (Con), 2) Con plus $0.3 \mathrm{mg} / \mathrm{kg}$ feed sodium selenite (SS); 3 ) Con plus $0.3 \mathrm{mg} / \mathrm{kg}$ feed Seyeast (SY): 4) Con plus $0.3 \mathrm{mg} / \mathrm{kg}$ feed bacterial enriched organic Se protein (ADS18) from Stenotrophomonas maltophilia bacteria. On d 116, hens were euthanized (slaughtered) to obtain blood (serum), liver organ, and breast tissue to measure antioxidant enzyme activity, biochemical profiles, and selenium concentration. The results show that antioxidant enzyme activity of hens was increased when fed bacterial organic Se (ADS18), resulting in a significant $(P<0.05)$ increase in serum GSH-Px, SOD, and CAT activity compared to other treatment groups. However, ADS18 and SY supplementation increase $(P<$ 0.05) hepatic TAC, GSH-Px, and CAT activity, unlike the SS and Con group. Similarly, dietary Se treatment reduced total cholesterol and serum triglycerides concentrations significantly $(P<0.05)$ compared to the Con group. At 16 and 18 weeks, selenium concentration in hen egg yolks supplemented with dietary Se was higher $(P<0.05)$ than in Con, with similar patterns in breast tissue and serum. Supplementation with bacterial organic Se (ADS18) improved antioxidant enzyme activity, decreased total serum cholesterol and serum lipids, and increased Se deposition in egg yolk, tissue, and serum. Hence, organic Se may be considered a viable source of Se in laying hens.

\section{Introduction}

In natural sciences, the term "antioxidant" is increasingly common as it gains attention because of its health advantages (Huang et al. 2005). Synthetic or natural substances applied to products to retard or avert their degradation by the action of oxygen in the air are a more bio-logically applicable concept of antioxidants (Sugiharto 2019; Cimrin et al. 2020). Dietary antioxidants are substances in food that, as described by the Institute of Medicine (Meyers 2000), significantly scavenge and reduce or inhibit the unfavorable effects of reactive species (oxidants), like oxygen or nitrogen species (ROS or RNS), prevent certain diseases, and promote normal physiological functions in living being (Salehi et al. 2018; Aziz et al. 2019). Dietary antioxidants primarily consist of free radicals, reactive oxygen species, metal chelators, enzyme inhibitors, and antioxidant enzyme cofactors (Huang et al. 2005). In a biological system, oxidation is promoted mainly by a host of redox enzymes. Nonenzymatic lipid oxidation, however, can still occur and ultimately result in cell oxidative stress (Kurutas 2016). Biological antioxidants, therefore, include enzymatic antioxidants (like glutathione peroxidase, catalase, and superoxide dismutase) and nonenzymatic antioxidants such as Vitamin E (Aksoz et al. 2020; Gouta et al. 2021) and Vitamin C (Chiaiese et al. 2019; Giuffrè 2019; Saracila et al. 2020), oxidative enzyme inhibitors (aspirin, cyclooxygenase, ibuprofen), antioxidant enzyme cofactors (Se, Coenzyme $Q_{10}$ ), meta chelators (EDTA) and scavenge reactive oxygen/nitrogen species (ROS/RNS) (Huang et al. 2005; Kurutas 2016). Biological antioxidants, according to (Halliwell 1990), are substances that "protect, prevent, or minimize the level of 
oxidative damage of biomolecules when present at minute concentrations compared to the biomolecules they protect. To produce high-quality livestock products, it is therefore important to use dietary antioxidants as they are capable of reducing lipid peroxidation in serum lipid profile, increases the antioxidant status and its concentration in the animal products, and providing benefits to both animals and humans health (Surai and Dvorska 2002).

Dietary selenium is important in animal nutrition especially the organic form which is highly available in animal tissues compared to inorganic sources for different physiological functions. Selenium required for various physiological functions in animals is a cofactor of selenoproteins (e.g., glutathione peroxidase) that reduces peroxides to alcohol and water (Dalia et al., 2017). Selenium is commonly supplemented in animal nutrition in an inorganic salt or organic form. Because of its biochemical and physiological functions in animals, organic Se is strongly retained in animal tissues relative to inorganic Se sources (Surai and Dvorska 2002; Canoğullari et al. 2010). Different sources of Se in animal tissues have different metabolic effects, according to studies published in the literature (Yuan et al. 2012; Boiago et al. 2014). Dietary supplementation of an antioxidant such as selenium can have a positive effect on the blood (biochemical or haematological) profile of animals. Blood is one of the most accurate markers of an animal's health status, and it can be affected by several factors including nutrition, disease, animal status, environmental, and climatic (Shi et al. 2018).

Blood biochemical index, in particular, may provide details about the animal's nutritional conditions (Mu et al. 2019) and health status (Reda et al. 2020), with aspartate aminotransferase (AST), alkaline phosphatase (ALP), alanine aminotransferase (ALT) and bilirubin, creatinine, uric acid, gamma-glutamyl transferase (GGT) as markers of liver and kidney oxidative injury (Abdel-Daim et al. 2020). Lower concentrations of these biochemical indices are related to enhanced antioxidant status and, as a result, the safer condition of kidneys and liver. The administration of biologically or chemically synthesized nano-Se to growing rabbits and laying hens decreased serum urea, triglycerides (TG), glutamyl transferase (GGT), albumin (ALB), and glutamate pyruvate transaminase (GPT), and enhanced the antioxidant markers (Sheiha et al. 2020; Zhou et al. 2021). Similarly, plasma creatinine, the activity of AST enzyme, and plasma total cholesterol, and plasma LDL concentrations all decreased in organic Se supplemented rabbits (Ayyat et al. 2018; Abdel-Azeem et al. 2019). Furthermore, when breeder quails were fed 0.5 to $2.5 \mathrm{~g} / \mathrm{kg}$ DL-methionine, lipid profile markers, and lactate dehydrogenase (LDH) activity were reduced (Reda et al. 2020). Broiler birds fed 0.1 to $0.5 \mathrm{mg} / \mathrm{kg}$ of feed nano-Se reduces blood ALB concentrations (Ahmadi et al. 2018), influenced oxidation resistance (Chen et al. 2013). Se supplementation raises total protein, albumin, total cholesterol, and TG in laying hens during the hot season while decreasing liver enzymes (ALT) and thyroid hormone (thyroxin) (Abd El-Hack et al. 2017).

The mechanisms through which Se functions are implemented exclusively by Se-containing proteins (Mangiapane et al. 2014; Wrobel et al. 2016). Selenocysteine is the major part of which, after absorption into selenoproteins, Se exercises its biological function in a system (Mahima et al. 2014). As a result, selenoprotein concentrations and selenoprotein mRNA yield are influenced by Se supply. In chicken, more dentified, all of which play important roles in the catalytic 
action of the enzyme. The synthesis of selenoproteins is influenced by nutritional levels of Se supplementation in the diet (Zhang et al. 2013; Dalia et al., 2017). A large number of studies have found a connection between dietary Se supplementation and selenoprotein expression in animal tissues.

Furthermore, laying hens with a Se supplemented diet had a significant elevation in antioxidant capacity (Han et al. 2017). Many studies have shown that supplementing the diet of laying hens with Se improves their antioxidant capacity (glutathione peroxidase, superoxide dismutase, and catalase) (Han et al. 2017; Sun et al. 2020). Supplementation with Se improves immune and antioxidant status (Sun et al. 2020), increases the content of selenium in eggs (Liu et al. 2020b), and prevents clinical problems due to deficiency of Se (Nabi et al. 2020). Mineral utilization is primarily determined by their bioaccumulation and retention (Li et al. 2018). The quantity and form of ingested Se determine how it is absorbed and stored in the body (Payne and Southern 2005).

Dietary Se supplementation increased Se deposition and concentration in eggs (Pan et al. 2011; Meng et al. 2019; Liu et al. 2020b). Selenium-fortified eggs can therefore be produced by supplementing the diet of hens with selenium. Compared to the widely used inorganic sodium selenite, organic Se has been reported to increases Se deposition in eggs and improve the quality of eggs (Liu et al. 2020a; Nabi et al. 2020). The efficacy of the organic form of selenium was due to its greater utilization and absorption compared to other selenite sources (Utterback et al. 2005; Delezie et al. 2014; Han et al. 2017). Liu et al. (2020c) reported that the addition of $0.5 \mathrm{mg} / \mathrm{kg}$ SY increases egg yolk Se compare to 0.3 and $0.5 \mathrm{mg} / \mathrm{kg}$ SS and $0.3 \mathrm{mg} / \mathrm{kg}$ SY. Furthermore, hens fed nano-Se and Se-yeast had a significant Se deposition in their egg, liver, and kidney (Meng et al. 2020).

To produce organic Se, different strains of microorganisms can be used in the microbial reduction pathway. Stenotrophomonas maltophilia (ADS18) has been linked to organic Se-containing proteins that can be used as Se sources in poultry (Dalia et al., 2017; Dalia et al. 2018). In laying hens, dietary Se (yeast or bacteria) improved antioxidant capacity, increased serum biochemical markers, and boosted Se deposition efficiency (meat, eggs, and blood) (Mohapatra et al., 2014; Han et al., 2017; Nasiri et al., 2019; Wang et al., 2019; Lu et al., 2020; Timur and Utlu 2020; Muhammad et al., 2021). Although Se may help the antioxidant system, there is little scientific evidence on the effect of this new organic Se source on layers. No published research on the effect of bacterial organic Se from the ADS18 source (Dalia et al. 2017), on antioxidant enzyme activity, blood biochemical parameters, and selenium concentration in layers has been recorded. In this study, the antioxidant enzyme activity, blood biochemical parameters, and selenium concentration in laying hens were examined utilizing bacterial organic Se as an alternative organic Se source with other selenium sources.

\section{Materials And Methods}

\section{Animal ethics}

This study was reviewed and approved by the Institutional Animal Care and Use Committee of University 
regulations for the administration affairs concerning experimental animals as stipulated.

\section{Animals Experimental Design And Diets}

A total of 14423 -wk-old Lohman Brown classic hens $(1702 \pm 183 \mathrm{~g})$ were divided into four equal groups, each 36 hens reared in a ventilated henhouse and two-tier stainless-steel cages with one hen per cage at Ladang 15, Universiti Putra Malaysia. The cage measured $30 \mathrm{~cm}$ in width, $50 \mathrm{~cm}$ in depth, and $40 \mathrm{~cm}$ in height. Except for Se, which was supplemented as $0.3 \mathrm{mg} / \mathrm{kg}$ feed according to (Surai 2006), a basal diet for laying hens was prepared according to NRC (National Research Council) (NRC 1994) guidelines (Table 1). Three supplemented diets were designated as control, basal diet $+0.3 \mathrm{mg} / \mathrm{kg}$ feed sodium selenite (SS), Se-yeast (SY), and bacterial organic Se (ADS18), respectively. The production and extraction of the bacterial Se content are described by (Dalia et al., 2017). The experimental diets were formulated with FeedLIVE software and adhered to the nutrient requirements of the Lohman management guide (2018), with hens limited to 120 grams per day. During the experimental process, the hens were fed a day (07:00-08:00) and had ad libitum access to water and treatment diets at an ambient temperature of approximately $30 \pm 5^{\circ} \mathrm{C}$ during the experimental phase. With the light beginning at 17:00 local time and following the Lohman Brown-Classic, (2018), a sixteen-hour light and eight-h dark lightning schedule were exercised. The feeding trial lasted for 16 weeks, with a four-week adaptation period. 
Table 1

Ingredient composition and analyzed nutrient concentration of the basal diet (on a dry matter basis).

\section{Ingredients}

Corn

Soybean Meal 48\%

Wheat Pollard

Crude Palm Oil

L-Lysine

DL-Methionine

Dicalcium Phosphate (18\%)

Calcium Carbonate

Choline Chloride

Salt

Mineral Mix ${ }^{\mathrm{a}}$

Vitamin Mix ${ }^{\mathrm{b}}$

Antioxidant $^{\mathrm{C}}$

Toxin Binder $^{\mathrm{d}}$

Total

Analysed composition

Metabolizable energy $\mathrm{Kcal} / \mathrm{Kg}$

Crude protein (\%)

Crude fat (\%)

Fibre (\%)

Calcium (\%)

Total phosphorus (\%)

Available phosphorus for poultry (\%)
$\%$

44.00

29.00

11.00

3.50

0.10

0.25

2.00

7.70

0.10

0.35

0.60

0.60

0.40

0.40

100.00

2761.24

17.66

5.30

3.98

3.65

0.88

0.48

a Mineral premix supplied (per kg of diet): $\mathrm{Cu}^{2+} 15 \mathrm{mg}, \mathrm{Zn}^{2+} 120 \mathrm{mg}, \mathrm{Fe}^{2+} 120 \mathrm{mg}, \mathrm{Mn}^{2+} 150 \mathrm{mg}$, iodine $1.5 \mathrm{mg}$, and cobalt $0.4 \mathrm{mg}$. 
${ }^{b}$ Vitamin premix supplied (per kg of diet): Vitamin A (retinyl acetate) $10.32 \mathrm{mg}$, vitamin E (DLtocopherol acetate) $90 \mathrm{mg}$, cholecalciferol $0.250 \mathrm{mg}$, vitamin K $6 \mathrm{mg}$, cobalamin $0.07 \mathrm{mg}$, thiamine 7 $\mathrm{mg}$, riboflavin $22 \mathrm{mg}$, niacin $120 \mathrm{mg}$, folic acid $3 \mathrm{mg}$, biotin $0.04 \mathrm{mg}$, pantothenic acid $35 \mathrm{mg}$ and pyridoxine $12 \mathrm{mg}$.

${ }^{\mathrm{c}}$ Antioxidant contains butylated hydroxyanisole (BHA).

${ }^{d}$ Toxin binder contains natural hydrated sodium calcium aluminum silicates to reduce the exposure of feed to mycotoxins.

e The Se content measured using ICP.MS.

${ }^{f}$ Feed live International Software (Nonthaburi, Thailand) was used to formulate the diets.

\section{Slaughtering, Blood, And Tissue Collection}

To collect blood and tissue samples, twenty-four hens were randomly selected from the four treatments (one from each replicate) and slaughtered according to Halal procedures, as defined in the Malaysian Standard (Malaysia 2009). Blood samples $(10 \mathrm{ml})$ were taken from each hen's jugular vein and collected in BD Vacutainer ${ }^{\circledR}$ Plus Plastic Serum Tubes (Becton Dickinson, New Jersey, USA) during slaughtering. Blood samples were centrifuged at $3,000 \times \mathrm{g}$ at $4^{\circ} \mathrm{C}$ for $10 \mathrm{~min}$, and the resultant supernatant (serum) was separated and stored at $-80^{\circ} \mathrm{C}$ for biochemical serum and antioxidant capacity analysis (Humam et al. 2021). For the antioxidant activity assay, a portion of liver tissue was sliced and snapped frozen in liquid nitrogen before being stored at $-80^{\circ} \mathrm{C}$. A portion of the breast muscle sample was snapped frozen in liquid nitrogen and stored at $-80^{\circ} \mathrm{C}$ for further assays.

\section{Determination Of Serum And Tissue Antioxidant Enzymes Activity}

The serum and liver were tested for total antioxidant capacity (T-AOC), glutathione peroxidase activity (GSH-Px), and total superoxide dismutase activity (T-SOD), catalase activity (CAT). Phosphate-buffered saline (PBS) was used to homogenize liver tissue on ice, then centrifuged at $3,000 \mathrm{xg}$ for $10 \mathrm{~min}$ at $4^{\circ} \mathrm{C}$ to extract supernatant for enzyme assays (Dalia et al., 2017; Humam et al. 2021).

Total antioxidant capacity (T-AOC) was measured from serum and liver using the QuantiChrom ${ }^{\mathrm{TM}}$ Antioxidant Assay Kit (DTAC-100, BioAssay Systems, Hayward, USA), following the manufacturer's instructions. The assay measures the total antioxidant capacity of the sample's antioxidant in which $\mathrm{Cu}^{2+}$ is reduced by antioxidant to $\mathrm{Cu}^{+}$, a colored complex with a dye is formed with a resulted $\mathrm{Cu}^{+}$, and the intensity of the color was proportional with the total antioxidant capacity present in the sample. The 
$245 \mu \mathrm{L}$ distilled water (1 mM Trolox) was prepared, and $20 \mu \mathrm{L}$ each of standards and samples was transferred into 96-well plate following the serial concentration and separate wells for samples, respectively. Working reagent for sample and standard was mixed, for each assay well, containing $100 \mu \mathrm{L}$ Reagent $A$ and $8 \mu \mathrm{L}$ of Reagent B. $100 \mu \mathrm{L}$ working reagent was added to all assay wells, gently tap to mix and incubate at room temperature for $10 \mathrm{~min}$. Finally, the absorbance of the TAC was read at $570 \mathrm{~nm}$ using a microplate reader (Multiskan Go, Thermo Scientific, Waltham, Massachusetts, USA) (Dalia et al., 2017; Humam et al. 2021). The standard curve was used to calculate the TAC activity in the serum and liver samples.

2.3.2. Glutathione peroxidase (GPx) activity was performed in serum and liver samples using EnzyChrom ${ }^{\text {TM }}$ Glutathione Peroxidase Assay Kit (EGPX-100, BioAssay Systems, Hayward, USA) following the manufacturer's instructions. The assay directly measures NADPH consumption in the enzymecoupled reactions. The measured reduction in optical density at $340 \mathrm{~nm}$ is directly proportional to the enzyme activity present in the sample. The detection range of the kit was 40 to $800 \mathrm{U} / \mathrm{L} \mathrm{GPx}$. Briefly, 10 $\mu \mathrm{L}$ of the samples added with $90 \mu \mathrm{L}$ of working reagent $(80 \mu \mathrm{L}$ assay buffer, $5 \mu \mathrm{L}$ glutathione, $3 \mu \mathrm{L}$ $\mathrm{HADPH}(35 \mathrm{mM})$, and $2 \mu \mathrm{L}$ GR enzyme) were transferred into the 96-microplate well and gently tap the plate for the mixture. A $100 \mu \mathrm{L}$ of the substrate solution was added immediately to each sample including control wells. The optical density of the samples and standards absorbance measurement was immediately measured at time zero (OD0), and at $4 \mathrm{~min}$ (OD4) using a microplate reader (Multiskan Go, Thermo Scientific, Waltham, Massachusetts, USA) at $340 \mathrm{~nm}$ (Dalia et al., 2017; Humam et al. 2021). The standard curve was a plot using NADPH standards. The standard curve was used to calculate the GPx activity in the serum and liver samples.

$$
G S H-P x \operatorname{Activity}(U / L)=\frac{\Delta O D S-\Delta O D B}{\operatorname{Slope}(m M-1) * 4(\min )} * 1000 * n
$$

where;

- $\triangle \mathrm{ODS}=(\mathrm{OD} 0-\mathrm{OD} 4)$ for the samples.

- $\triangle \mathrm{ODB}=(\mathrm{ODO}-\mathrm{OD} 4)$ for the background control.

- The factor 1000 converts mmoles to $\mu$ moles.

- $\mathrm{N}$ is the sample dilution factor.

Superoxide dismutase (SOD) activity was performed for serum and liver using EnzyChrom ${ }^{\text {TM }}$ Superoxide Dismutase Assay Kit (ESOD-100, BioAssay Systems, Hayward, USA) following the manufacturer's instructions. The assay relies on the addition of xanthine oxidase $(\mathrm{XO})$ to the samples as a source of superoxide $\left(\mathrm{O}_{2}{ }^{-}\right)$. The $\mathrm{O}_{2}{ }^{-}$forms a colored product as it interacts with a specific (WST-1) dye. The sample's SOD activity, which acts as a superoxide scavenger, scavenges the $\mathrm{O}_{2}{ }^{-}$, thus lowering the color intensity. The kit has a detection range of 0.05 to $3 \mathrm{U} / \mathrm{mL}$ SOD. A microplate reader (Multiskan Go, Thermo Scientific, Waltham, Massachusetts, USA) set to $440 \mathrm{~nm}$ was used to calculate the color intensity 
indicating SOD activity in a sample. The concentration of SOD in the samples was calculated using the standard curve.

Catalase (CAT) activity was measured from serum and liver using the EnzyChrom ${ }^{\text {TM }}$ Catalase Assay Kit (ECAT-100, BioAssay Systems, Hayward, USA), following the manufacturer's instructions. The assay measures the degradation of $\mathrm{H}_{2} \mathrm{O}_{2}$ using a redox dye, and the detection range of the kit was 0.2 to $5 \mathrm{U} / \mathrm{L}$ CAT. As described, $10 \mu \mathrm{L}$ of the sample, positive control, and assay buffer as blank plus $90 \mu \mathrm{L}$ of substrate buffer $(50 \mu \mathrm{M})$ were loaded into 96 micro-plate wells, gently shaken, and incubated at room temperature for $30 \mathrm{~min}$. While waiting for incubation time, the standard curve was prepared by mixing 40

$\mu \mathrm{L}$ of the $4.8 \mathrm{mM} \mathrm{H}_{2} \mathrm{O}_{2}$ reagent with $440 \mu \mathrm{L}$ of distilled water in the serial concentration, then $10 \mu \mathrm{L}$ of the standard solution with $90 \mu \mathrm{L}$ of assay buffer were placed into standard wells. At the end of incubation time, $100 \mu \mathrm{L}$ of detection reagent was mixed in each well and incubated for $10 \mathrm{~min}$ at room temperature. A microplate reader (Multiskan Go, Thermo Scientific, Waltham, Massachusetts, USA) was used to read the optical density of CAT at $570 \mathrm{~nm}$ (Dalia et al., 2017; Humam et al. 2021). The CAT activity in the serum and liver samples was calculated using the standard curve.

\section{Blood Biochemical Assay}

The biochemical parameters measured were activities of enzymes (AST, ALP, ALT, and GGT), and concentration of metabolites creatinine, cholesterol, triglycerides, $L D L$, high-density lipoprotein $(H D L)$, very low-density lipoprotein (VLDL) and lactate dehydrogenase (LDH), total protein, total bilirubin, ALB, globulin, and urea. All constituents were measured using an Auto-blood biochemical analyzer (Automatic Analyser 902, Hitachi, Germany), except serum globulin and albumin/globulin ratio (A/G), which were extrapolated as follows: $\mathrm{G}$ = total protein - albumin, $\mathrm{A} / \mathrm{G}$ = albumin/globulin (Abdel-Azeem et al. 2019). All samples were run in replicates.

\section{Determination of egg yolk, breast tissue, and serum selenium concentration}

Eggs were collected, broken, and fractionated into albumen and yolk. They were capped in a container, frozen $\left(>24 \mathrm{~h}\right.$ ) at $-80^{\circ} \mathrm{C}$, and lyophilized at $-50^{\circ} \mathrm{C}$ for $72 \mathrm{~h}$ (Labconco FreeZone plus 6, USA), and stored in $-20^{\circ} \mathrm{C}$ until further analysis (Lipiec et al. 2010; Tufarelli et al. 2016). The lyophilized samples were ground to powder using porcelain mortar and pestle and stored at $4^{\circ} \mathrm{C}$. All chemicals/reagents were of analytical grade purchased from Sigma-Aldrich (Saint-Quentin Fallavier, France) and were used throughout the analysis unless stated differently with the dilutions prepared daily. The procedure of total selenium determination of egg yolk as described (Lipiec et al. 2010), tissues (Jagtap and Maher 2016) was followed with modifications. Briefly, approximately $0.5 \mathrm{~mL}$ serum and lyophilized $0.5 \mathrm{~g}$ egg yolk and breast tissue each were weighed into $10 \mathrm{ml}$ Teflon digestion vessels (A. I. Scientific, Australia) and $5 \mathrm{ml}$ of concentrated $\mathrm{HNO}_{3}$ (Sigma-Aldrich, USA) and $3 \mathrm{~mL} \mathrm{H}_{2} \mathrm{O}_{2}$ (Emsure® ISO, Merck) added. Digestion was carried out in DigiPrep (SCP Science, Courtaboeuf, France) to heat the samples for $4 \mathrm{~h}$ at $100^{\circ} \mathrm{C}$ starting at a lower temperature $\left(65^{\circ} \mathrm{C}\right.$ ) for $30 \mathrm{~min}$ (approximately) and raises gradually. The vessel was allowed to Loading [MathJax]/jax/output/CommonHTML/jax.js 
cool for $60 \mathrm{~min}$ at room temperature $\left(25^{\circ} \mathrm{C}\right)$ after digestion and then diluted with distilled or deionized water in a polyethylene vial to a final volume of $10 \mathrm{ml}$. Total Se concentration in diluted digest was determined with a Perkin Elmer DRC-e ICP-MS with calibrations performed every 20 samples. The quantification (external calibration) was carried out by preparing standard of five different concentrations $(0.0,0.2,0.4,0.6,0.8$ and $1.0 \mathrm{mg} / \mathrm{L})$. The ICP MS collision was pressurized with hydrogen. All the samples were injected via a Micromist nebulizer fitted with a Scott double-pass spray chamber for determination (Lipiec et al. 2010).

\section{Statistical analysis}

All data analyses were performed using the Statistical Analysis System (SAS) 9.4 Version (SAS Institute, Cary, North Carolina, USA) in a completely randomized design. The data were analyzed by the General Linear Model (GLM) procedure of SAS and Duncan Multiple Range Test was used to separate means. The significant differences between the treatments each with six replicates were established at a $P$-value $<0.05$ level. In all figures and tables, the results were presented as mean \pm SEM.

\section{Results}

\section{Antioxidant enzyme activity in serum and liver}

The effects of different dietary Se supplementation on the antioxidant enzyme activities of TAC, GSH-Px, SOD, and CAT in laying hen serum and liver (Fig. 1) were summarized. The Se-yeast group had significantly $(P<0.05)$ higher serum TAC activity than did the ADS18, SS, and basal diet groups. Furthermore, supplementation with bacterial organic Se of ADS18 resulted in a significant $(P<0.05)$ increase in serum SOD, and CAT activity when compared to other groups, but GSH-Px activity was similar to the Se-yeast group. The results of GSH-Px activity in SS and non-supplemented hens were not significantly $(P>0.05)$ different. The Se-yeast, SS, and control groups did not differ $(P>0.05)$ significantly in terms of CAT activity. When compared to basal diets, bacterial organic Se (ADS18), Se-yeast and SS supplementation result in a significant $(P<0.05)$ increase in hepatic TAC, GSH-Px, and CAT activity. Furthermore, hepatic GSH-Px activity was decreased in the Con group, and it differed significantly $(P<$ $0.05)$ from the ADS18 and Se-yeast groups, but was similar to the SS group. ADS18 and Se-yeast-fed hens had increased $(P<0.05)$ liver CAT activity than sodium selenite or control treatments. Dietary Se had no effect $(P>0.05)$ on laying hens' hepatic SOD activity in any of the treatment groups. Despite the lack of a regular trend, Se supplementation in any form (inorganic or organic) was associated with a significant $(P<0.05)$ increase in liver antioxidant indicators when compared to the basal diet.

\section{Serum Biochemical Parameters}

Table 2 summarizes the effect of dietary Se treatments on serum biochemical parameters in 39-weeksold lavina hens. There were no sianificant $(P>0.05)$ differences in plasma proteins (total protein, serum Loading [MathJax]/jax/output/CommonHTML/jax.js 
albumin, globulin, albumin globulin ratio), kidney markers (gamma-glutamyl transpeptidase, total bilirubin, creatinine, urea), or uric acid between treatment groups. Hens fed ADS18, Se-yeast, or SS diets showed a decrease $(P<0.05)$ serum AST and ALP activities. There was no significant difference $(p>$ $0.05)$ in serum ALT activities, as the dietary treatment groups values were all less than four units per liter $(\mathrm{U} / \mathrm{L})$.

The ADS18, Se-yeast, or SS-supplemented groups had significantly $(P<0.05)$ reduced serum total cholesterol concentrations than did the control group. Serum triglycerides and VLDL were significantly $(P$ $<0.05)$ lower in the ADS18 and Se-yeast dietary Se treatment groups than in the SS and control groups, while the SS and SY groups differ significantly $(P<0.05)$ in HDL. However, there was no significant $(P>$ $0.05)$ differences in LDL and LDH concentrations in either of the dietary treatment groups. There was no significant difference $(P>0.05)$ in serum uric acid concentrations between the dietary treatment groups. 
Table 2

Serum biochemical profiles of laying hens fed different selenium sources

\begin{tabular}{|c|c|c|c|c|c|c|}
\hline \multirow[t]{2}{*}{ Parameters } & \multicolumn{4}{|c|}{ Experimental diets } & \multirow{2}{*}{$\begin{array}{l}P- \\
\text { value }\end{array}$} & \multirow[t]{2}{*}{ Ref } \\
\hline & Con & SS & SY & ADS18 & & \\
\hline \multicolumn{7}{|l|}{ Plasma proteins } \\
\hline $\begin{array}{l}\text { Total Protein } \\
(\mathrm{g} / \mathrm{L})\end{array}$ & $51.10 \pm 2.10$ & $53.92 \pm 0.48$ & $\begin{array}{l}51.10 \pm \\
2.01\end{array}$ & $\begin{array}{l}54.52 \pm \\
1.84\end{array}$ & 0.375 & $17-49$ \\
\hline Albumin $(\mathrm{g} / \mathrm{L})$ & $16.45 \pm 0.53$ & $17.68 \pm 0.38$ & $\begin{array}{l}16.83 \pm \\
0.46\end{array}$ & $\begin{array}{l}16.75 \pm \\
0.69\end{array}$ & 0.407 & $8-28$ \\
\hline Globulin $(\mathrm{g} / \mathrm{L})$ & $34.65 \pm 1.98$ & $36.23 \pm 0.63$ & $\begin{array}{l}34.27 \pm \\
1.81\end{array}$ & $\begin{array}{l}37.15 \pm \\
1.99\end{array}$ & 0.604 & $4-21$ \\
\hline $\begin{array}{l}\text { Albumin Globulin } \\
\text { Ratio }\end{array}$ & $\begin{array}{l}0.480 \pm \\
0.025\end{array}$ & $\begin{array}{l}0.489 \pm \\
0.023\end{array}$ & $\begin{array}{l}0.496 \pm \\
0.022\end{array}$ & $\begin{array}{l}0.493 \pm \\
0.027\end{array}$ & 0.968 & $2-5.2$ \\
\hline \multicolumn{7}{|l|}{$\begin{array}{l}\text { Kidneys } \\
\text { functions }\end{array}$} \\
\hline GGT (U/L) & $\begin{array}{l}16.333 \pm \\
3.92\end{array}$ & $\begin{array}{l}15.333 \pm \\
3.68\end{array}$ & $\begin{array}{l}13.000 \pm \\
4.58\end{array}$ & $\begin{array}{l}12.667 \pm \\
3.46\end{array}$ & 0.891 & NA \\
\hline $\begin{array}{l}\text { Total bilirubin } \\
\text { (umol/L) }\end{array}$ & $1.767 \pm 0.19$ & $1.850 \pm 0.14$ & $\begin{array}{l}1.533 \pm \\
0.14\end{array}$ & $1.72 \pm 0.12$ & 0.501 & NA \\
\hline $\begin{array}{l}\text { Creatinine } \\
\text { (umol/L) }\end{array}$ & $18.00 \pm 0.73$ & $18.00 \pm 0.93$ & $\begin{array}{l}18.17 \pm \\
1.33\end{array}$ & $\begin{array}{l}16.50 \pm \\
1.57\end{array}$ & 0.730 & $9-71$ \\
\hline Urea (mmol/L) & $0.233 \pm 0.03$ & $0.267 \pm 0.05$ & $\begin{array}{l}0.283 \pm \\
0.05\end{array}$ & $\begin{array}{l}0.317 \pm \\
0.03\end{array}$ & 0.557 & $\begin{array}{l}0.41- \\
2.14\end{array}$ \\
\hline \multicolumn{7}{|l|}{ Liver functions } \\
\hline AST (U/L) & $\begin{array}{l}270.33 \pm \\
16.12^{\mathrm{a}}\end{array}$ & $\begin{array}{l}254.67 \pm \\
13.12^{\mathrm{ab}}\end{array}$ & $\begin{array}{l}225.00 \pm \\
13.34^{\mathrm{b}}\end{array}$ & $\begin{array}{l}219.00 \pm \\
7.74^{b}\end{array}$ & 0.033 & $\begin{array}{l}115- \\
290\end{array}$ \\
\hline $\operatorname{ALP}(\mathrm{U} / \mathrm{L})$ & $\begin{array}{l}356.00 \pm \\
33.87^{\mathrm{ab}}\end{array}$ & $\begin{array}{l}419.33 \pm \\
48.47^{a}\end{array}$ & $\begin{array}{l}270.83 \pm \\
40.58^{b}\end{array}$ & $\begin{array}{l}268.50 \pm \\
28.32^{b}\end{array}$ & 0.032 & \\
\hline ALT (U/L) & $<4$ & $<4$ & $<4$ & $<4$ & NA & $<8$ \\
\hline \multicolumn{7}{|l|}{ Plasma lipids } \\
\hline $\begin{array}{l}\text { Cholesterol } \\
(\mathrm{mmol} / \mathrm{L})\end{array}$ & $\begin{array}{l}3.517 \pm \\
0.201^{\mathrm{a}}\end{array}$ & $\begin{array}{l}3.167 \pm \\
0.145^{\mathrm{ab}}\end{array}$ & $\begin{array}{l}2.833 \pm \\
0.233^{\mathrm{bc}}\end{array}$ & $\begin{array}{l}2.617 \pm \\
0.075^{c}\end{array}$ & 0.009 & NA \\
\hline
\end{tabular}

The enzyme unit ( $\mu \mathrm{mol} / \mathrm{min}$ ) is a measure of enzyme catalytic activity. GGT gamma-glutamyl transpeptidase, AST aspartate aminotransferase, ALP alkaline phosphatase, ALT alanine aminotransferase, LDL low-density lipoprotein cholesterol, HDL high-density lipoprotein cholesterol, VLDL very-low-density lipoprotein cholesterol, LDH lactate dehydrogenase. Data represent mean \pm SD of six replicates of six hens. ${ }^{a-c}$ Means vary significantly within a row with different superscripts $(P<$ Loading [MathJax]/jax/output/CommonHTML/jax.js tt available. 


\begin{tabular}{|c|c|c|c|c|c|c|}
\hline \multirow[t]{2}{*}{ Parameters } & \multicolumn{4}{|c|}{ Experimental diets } & \multirow{2}{*}{$\begin{array}{l}P \text { - } \\
\text { value }\end{array}$} & \multirow[t]{2}{*}{ Ref } \\
\hline & Con & SS & SY & ADS18 & & \\
\hline $\begin{array}{l}\text { Triglyceride } \\
(\mathrm{mmol} / \mathrm{L})\end{array}$ & $\begin{array}{l}14.685 \pm \\
1.175^{a}\end{array}$ & $\begin{array}{l}12.332 \pm \\
1.133^{a}\end{array}$ & $\begin{array}{l}7.863 \pm \\
1.325^{b}\end{array}$ & $\begin{array}{l}8.875 \pm \\
0.612^{b}\end{array}$ & 0.001 & NA \\
\hline LDL (mmol/L) & $\begin{array}{l}1.235 \pm \\
0.185\end{array}$ & $\begin{array}{l}0.995 \pm \\
0.055\end{array}$ & $\begin{array}{l}1.478 \pm \\
0.408\end{array}$ & $\begin{array}{l}1.165 \pm \\
0.093\end{array}$ & 0.531 & NA \\
\hline HDL (mmol/L) & $\begin{array}{l}0.158 \pm \\
0.008 \text { ab }\end{array}$ & $\begin{array}{l}0.140 \pm \\
0.003^{b}\end{array}$ & $\begin{array}{l}0.193 \pm \\
0.003^{\mathrm{a}}\end{array}$ & $\begin{array}{l}0.165 \pm \\
0.011^{\mathrm{ab}}\end{array}$ & 0.022 & NA \\
\hline VLDL (mmol/L) & $2.94 \pm 0.23^{a}$ & $2.47 \pm 0.23^{a}$ & $1.57 \pm 0.27^{b}$ & $1.78 \pm 0.12^{b}$ & 0.001 & NA \\
\hline LDH (U/L) & $\begin{array}{l}448.17 \pm \\
33.73\end{array}$ & $\begin{array}{l}409.83 \pm \\
29.79\end{array}$ & $\begin{array}{l}418.50 \pm \\
69.72\end{array}$ & $\begin{array}{l}326.67 \pm \\
29.49\end{array}$ & 0.273 & $\begin{array}{l}1010- \\
2489\end{array}$ \\
\hline \multicolumn{7}{|c|}{ Antioxidative status } \\
\hline $\begin{array}{l}\text { Uric Acid } \\
\text { (umol/L) }\end{array}$ & $\begin{array}{l}153.0 \pm \\
22.89\end{array}$ & $\begin{array}{l}199.83 \pm \\
32.32\end{array}$ & $\begin{array}{l}216.0 \pm \\
53.61\end{array}$ & $\begin{array}{l}165.0 \pm \\
30.85\end{array}$ & 0.6061 & NA \\
\hline \multicolumn{7}{|c|}{$\begin{array}{l}\text { The enzyme unit ( } \mu \mathrm{mol} / \mathrm{min}) \text { is a measure of enzyme catalytic activity. GGT gamma-glutamyl } \\
\text { transpeptidase, AST aspartate aminotransferase, ALP alkaline phosphatase, ALT alanine } \\
\text { aminotransferase, LDL low-density lipoprotein cholesterol, HDL high-density lipoprotein cholesterol, } \\
\text { VLDL very-low-density lipoprotein cholesterol, LDH lactate dehydrogenase. Data represent mean } \pm \text { SD } \\
\text { of six replicates of six hens. a-c Means vary significantly within a row with different superscripts }(P< \\
0.05) \text {. NA is not statistically analyzed or not available. }\end{array}$} \\
\hline
\end{tabular}

\section{Egg Yolk, Breast Tissue, And Serum Selenium Concentration}

As a study baseline, the egg yolk Se concentration in each treatment was measured three days after commencing the treatment diets and found to be comparable $(P>0.05)$ in all groups. However, selenium concentrations in egg yolks of hens supplemented with dietary Se were higher $(P<0.05)$ than in hens fed a basal diet at the end (16-wks) of the experimental period (Fig. 2a) and 14 days post-storage $\left(4^{\circ} \mathrm{C} \pm 2\right)$ after the experiment (18-wks) (Fig. 2b). For fresh and stored egg yolk, organic Se supplemented hens showed greater yolk Se contents than inorganic SS and the basal diet. Except for the SS group, which had significantly higher $(P<0.05)$ yolk Se concentrations than did hens fed the control at the end of the experiment (16-wks) and 14-days post stored eggs (18-wks), no significant $(P<0.05)$ differences were found between the ADS18 and Se-yeast egg yolk Se concentrations at 16-wks (fresh) and 18-wks (stored). Between 16 and 18 weeks, the concentrations of egg yolk Se in all treatment groups were statistically identical, indicating that storage had no effect on egg yolk Se concentration and that there was a significant $(P<0.05)$ difference over the experimental period (Fig. 2b).

Se concentrations in breast tissue and serum increased $(P<0.05)$ in hens given dietary Se compared to the non-supplemented group (Table 3). Organic Se (ADS18 or Se-yeast) treatment groups had no Loading [MathJax]/jax/output/CommonHTML/jax.js at Se concentrations, but they were significantly higher $(P<$ 
$0.05)$ than those for inorganic and non-supplemented hens. Similarly, hens provided bacterial organic supplementation had the highest $(P<0.05)$ serum Se concentration compared to non-supplemented hens. The serum Se concentration of the hens was ADS18 > Se-yeast > SS and control or basal diet, in that order.

Table 3

Breast tissue and serum selenium concentration of laying hens fed organic and inorganic Se sources

\begin{tabular}{|c|c|c|c|c|c|}
\hline \multirow[t]{2}{*}{ Parameters } & \multicolumn{4}{|c|}{ Experimental diets* } & \multirow[t]{2}{*}{$P$-value } \\
\hline & Con & SS & SY & ADS18 & \\
\hline $\begin{array}{l}\text { Breast muscle } \\
(\mu \mathrm{g} / \mathrm{g})\end{array}$ & $\begin{array}{l}0.052 \pm \\
0.001^{\mathrm{c}}\end{array}$ & $\begin{array}{l}0.056 \pm \\
0.001^{\mathrm{b}}\end{array}$ & $\begin{array}{l}0.087 \pm \\
0.001^{a}\end{array}$ & $\begin{array}{l}0.086 \pm \\
0.002^{a}\end{array}$ & $<.0001$ \\
\hline Serum $(\mu \mathrm{g} / \mathrm{ml})$ & $\begin{array}{l}0.044 \pm \\
0.000^{d}\end{array}$ & $\begin{array}{l}0.052 \pm \\
0.001^{\mathrm{c}}\end{array}$ & $\begin{array}{l}0.054 \pm \\
0.001^{\mathrm{b}}\end{array}$ & $\begin{array}{l}0.059 \pm \\
0.001^{\mathrm{a}}\end{array}$ & $<.0001$ \\
\hline
\end{tabular}

\section{Discussion}

Animal wellbeing may be achieved by enhanced antioxidant capacity (Li et al. 2018). CAT, SOD, and GSH$\mathrm{Px}$, and lactoferrin, carotene, vitamin C, glutathione (GSH) as non-enzymatic constituents, are antioxidant enzymes metabolites in physiological antioxidant systems (Eşrefoğlu 2009). The main seleniumdependent enzymes are; glutathione peroxidases (GSH-Px) which catalyze $\mathrm{H}_{2} \mathrm{O}_{2}$ and ROS to water (Behne and Kyriakopoulos 2001), superoxide dismutase (SOD) catalyzes superoxide anion to $\mathrm{H}_{2} \mathrm{O}_{2}$ and molecular $\mathrm{O}_{2}$ (Okado-Matsumoto and Fridovich 2001), and catalase (CAT) catalyze hydrogen peroxide decomposition to yield water and oxygen, thus, protecting cells from oxidative damage (Nandi et al. 2019). Hence, dietary Se supplementation enhanced antioxidant capacity in animals (Surai and Dvorska 2002).

In general, the efficacy of organic Se over bioavailability and tissue retention is superior to that of inorganic Se. Minerals' utilization is dependent on their bioaccumulation and retention (Li et al. 2018). Similarly, compared to inorganic, dietary organic, and Nano-Se supplementation could improve the concentration of breast muscles, liver, and serum Se (Mohapatra et al. 2014; Mohamed et al. 2020), possibly resulting in greater activity of GSH-Px. Additive supplementation (e.g. Se) improves the activity of antioxidant enzymes in chickens through antioxidant capacity (Mohapatra et al. 2014; Markovic et al. 2018).

In the present study, organic Se bacteria (ADS18) and yeast (Se-yeast) have demonstrated stronger antioxidant activity in laying hens serum and liver compared to inorganic (sodium selenite) Se and nonsupplemented hens, in line with previous findings. The serum TAC value was significantly higher in the Loading [MathJax]/jax/output/CommonHTML/jax.js e control group, and Se-yeast supplementation also 
enhanced serum CAT and SOD activity in Brown Hy-line hens (Meng et al. 2020). Moreover, compared to positive control groups of local Chinese yellow male chickens infected with Eimeria tenella, (Mengistu et al. 2020) reported higher serum SOD and GSH-Px1 activities with Se-enriched probiotics. Xia et al. (2020) observed a linear and quadratic increase in liver GSH-Px1 and SOD activity in breeder ducks with increased dietary Se levels. In T-2 toxin (T-2) or HT-2 toxin (HT-2)-induced cytotoxicity and oxidative stress broiler hepatocytes, Yang et al. (2019) observed a significant increase in hepatic GSH-Px, SOD, and CAT activity that was activated by toxins with $1 \mu \mathrm{M}$ DL-Selenomethionine. Also, relative to those laying hens fed with the basal diet, Meng et al. (2019) reported an improvement in serum GSH-Px, T-AOC, and CAT activities in the nano-Se or sodium selenite group. Dalia et al. (2017) found the highest serum GSH-Px activity and CAT liver with bacterial organic Se supplementation of ADS18, respectively. Li et al. (2017) reported increased serum and breast GSH-Px activity with Se-yeast, Met-Se, and Nano-Se dietary supplementation compared with the SS group. Selenium is an indispensable constituent of the GSH-Px enzyme, actively involved in oxidative damage defense (Rotruck et al., 1973; Fernández-Lázaro et al., 2020).

In this study, the enzyme's activity was significantly enhanced by Se supplementation (organic) in serum and liver. The response of external stimuli and free radicals' metabolism capacity in organisms can be assayed by T-AOC (Huma et al., 2019). The body's total antioxidant capacity can be measured through TAC values (Zhang et al. 2011), with low or higher T-AOC suggesting oxidative stress or susceptibility to oxidative damage, respectively (Meng et al. 2020). Consequently, dietary supplementation with organic Se of ADS18 bacteria or Se-yeast could promote the antioxidant capacity of laying hens, thereby ensuring that egg-laying efficiency is preserved. The potential reason was that ADS18 or Se-yeast contains organic $\mathrm{Se}$, which is much less harmful and more bioavailable and effectively preserved in the tissues of the body.

Furthermore, hens supplemented with Se (regardless of Se form) improves all the measured antioxidant indexes except SOD which was not affected by dietary Se treatments in the liver. In summary, with the addition of bacterial organic Se, the serum and liver TAC, GSH-Px, CAT, and SOD activities produced by the cells to prevent the occurrence of oxidative damage (Xu et al. 2016; Yang et al. 2019), were further enhanced, indicating that the bacterial organic Se of ADS18 could partially reduce oxidative damage by regulating the activities of enzymes (antioxidases). Although catalase and superoxide dismutase are not Se-dependent enzymes for their functions, the presence of Se in animal rations can influence their activities via thyroid hormone metabolism (Meng et al. 2020; Mohamed et al. 2020).

Markers of nutritional conditions in growing animals may be serum biochemical parameters (Mu et al. 2019). The maintenance of plasma osmotic pressure, provision of energy, repairing the worn-out tissue, carrier, and transporter of nutrients to sustain body tissue protein, active balance of cells is the role of albumin protein, which is synthesized in the liver (Surai 2002). Liu et al. (2020a) found no major variations in albumin, total protein, or blood urea nitrogen after adding 0.3 and $0.5 \mathrm{mg} / \mathrm{kg}$ addition of sodium selenite and selenium yeast, respectively. Similarly, Hossein Zadeh et al. (2018) did not note any yanic or inorganic forms of Se. 
Different Se sources supplementation did not affect blood albumin, total protein, globulin, or the albumin globulin ratio in this study. Besides, as kidney function makers, gamma-glutamyl transpeptidase, total bilirubin, creatinine, and urea have not been affected and are per the previous reports (Kumar et al. 2008; Alimohamady et al. 2013; Sethy et al. 2015). Se has a greater impact on serum biochemical parameters, with a significant impact on lipid metabolism and a lesser impact on liver functions. The decreased total cholesterol, triglycerides, and VLDL observed as a result of supplementation with Se-yeast or ADS18 showed that the organic form of Se could play an anabolic role in fat deposition than the inorganic source of Se (Jeyanthi 2010; Sheoran 2017). Besides, the composition of fatty acids in the whole body could be modulated by supplementation Se via organic forms in yeast or bacteria. In a research study conducted by Dhingra and Bansal (2006) and Yang et al. (2010), they reported dietary Se supplementation plays a role in increasing the activity of LDL receptor, but, reduces the expression of 3hydroxy 3-methylgluatryl coenzyme A (HMG-CoA) reductase in rat and also invariably decrease serum LDL and cholesterol.

The results of this research were inconsistent with the study by Abdel-Azeem et al. (2019) and Amer et al. (2018), which showed the hypolipidemic effect of organic selenium (Se-yeast) in wean male rabbits by significantly reducing serum total cholesterol and LDL-cholesterol. In an in vitro study with Wistar rats, Urbankova et al. (2021) reported that Se deficiency tends to result in increased total cholesterol, LDL, and a significant decrease in HDL concentrations. Antioxidants' hypocholesterolemic activity may be due to oxysterols' inhibition of sterol biosynthesis (Revilla et al. 2009; Hozzein et al. 2020). Consequently, the antioxidant effect is principally attributed to selenoenzymes, glutathione peroxidase (GPX's), and thioredoxin reductase. In studies with growing pullets, Jegede et al. (2012) showed that, compared to CuSO4, supplementary trace (Cu-P) minerals reduced plasma cholesterol, LDL, and triglycerides. Kim et al. (1992) showed that the mechanism of $\mathrm{Cu}$ is to control cholesterol biosynthesis by reducing hepatic glutathione concentration and changes the hepatic GSH: GSSG (oxidized glutathione) ratio, thereby, increased the activity of 3-hydroxyl-3-methylglutaryl Co-(HMG-CoA) reductase. Glutathione plays an important role in regulating cholesterol biosynthesis via HMG-CoA reductase stimulation (Konjufca et al. 1997), which is the primary enzyme of cholesterol biosynthesis, and in turn, decreases plasma cholesterol concentration. The above-mentioned pathway can explain the reduction in plasma cholesterol by supplementing the organic form of Se.

Organic Se supplementation (Se-yeast or ADS18) has demonstrated a significant decrease in triglyceride concentration relative to inorganic and non-supplemented hens in the present study. These findings were consistent with the results of Jegede et al. (2012), who reported a significant decrease in triglyceride concentration in growing pullets supplemented with Cu-P compared to CuSO4. Moreover, dietary Se appears to have a major effect on aspartate aminotransferase (AST), alkaline phosphatase (ALP), but no effect on alanine aminotransferase (ALT) in the present study. Sizova et al. (2021) observed a substantial increase in ALT activity in broilers fed organic zinc on days 35 and 42, compared to control, though AST did not change significantly. Broiler chickens fed 0.3 ppm organic Se (Perić et al. 2009), 0.5 and $1.0 \mathrm{mg}$ Se per Kg had significantly lower ALT and AST enzyme activity (Biswas et al., 2011). 
In contrast, none of the blood constituents ALT, AST, TP, albumin, urea, and creatinine are affected by either inorganic ( 0.5 and $0.15 \mathrm{mg} \mathrm{Se}$ ) or organic $(0.35 \mathrm{mg} \mathrm{Se}$ ) (Okunlola et al. 2015). Blood enzymes (ALT, AST, ALP, LDH) cause oxidative damage to the liver and kidneys, which can be reduced, imparted, and enhanced through redox status to protect against oxidative damage (Zhang et al. 2018).

The concentration of Se in egg yolk, breast muscle, and serum increased after dietary Se supplementation with Se, according to this study. Avian eggs are ideal vectors used to study the absorption and retention of microminerals, including Se at varying dosages and forms (Pan et al. 2007; Delezie et al. 2014). Dietary supplementation with Se increased egg yolk Se in the current study, which is consistent with previous studies (Liu et al. 2020b; Zhang et al. 2020). Lu et al. (2020) found higher Se concentrations in eggs and breast tissue of laying hens fed 0.1 to $0.4 \mathrm{mg} / \mathrm{kg}$ of Se from Se-enriched yeast than in eggs and breast tissue of hens fed SS or basal diet. Also, Liu et al. (2020a) found that 0.5 $\mathrm{mg} / \mathrm{kg}$ of Se-yeast resulted in higher Se deposition in egg yolk than did sodium selenite in laying hens. According to Zhang et al. (2020), adding Se-yeast to the diets of laying hens helps to increase Se deposition in eggs. Likewise, hens fed with hydroxy selenomethionine and Se-yeast had higher concentration yolk Se than when fed the SS and basal diets (Moslehi et al. 2019).

Dietary Se supplementation with Vitamin E, Se, and their blend significantly increased the concentration of Se in breast tissue and certain laying hens' organs (Çelebi 2019). Similar results were found in eggs and breast meat Se concentration in laying hens (Lu et al. 2019; Lv et al. 2019), serum, liver, and muscle Se in growing lambs fed different concentrations ( 0.2 to $1.4 \mathrm{mg} / \mathrm{kg} \mathrm{DM}$ ) and Se sources (Se-met or Seyeast and SS) (Paiva et al. 2019). Hens fed organic Se showed higher egg Se content compared to inorganic Se in response to the effectiveness of organic Se over inorganic form (Skřivan et al. 2006; Chantiratikul et al. 2008).

The difference in Se deposition in egg yolk between inorganic and organic Se sources may be due to their dissimilar metabolizable pathways, as SS cannot be completely metabolized to SeMet in poultry, which could explain the current findings (Sunde et al. 2016). Sodium selenite has a lower absorption rate and a higher excretion than organic Se (Mahan and Parrett 1996). Organic Se is actively absorbed and is dependent on the metabolization and integration of mainly organic selenomethionine with methionine into egg proteins and tissues (Čobanová et al. 2011; Surai and Kochish 2019). Selenoproteins from the liver are incorporated as part of egg yolk synthesis, whereas the uterine tubes incorporate selenomethionine as a part of egg white synthesis (Mahan and Kim 1996; Lv et al. 2019). The higher Se deposition in hens' eggs fed Se-yeast might perhaps be connected to the upregulation of methionine (Met) metabolism gene glycine N-methyltransferase (GNMT) in the liver (Meng et al. 2019). With different Se levels and time, there is a positive increase in egg Se concentration (Lu et al. 2019).

As hypothesized, with dietary Se supplementation, the concentration of Se in breast tissue and serum of laying hens was increased, and organic Se (ADS18 or Se-yeast) was more efficient compared to inorganic Se. Paiva et al. (2019) relate serum Se concentration to time and dose-dependent regardless of Se form. Annlication of $\cap 3 \cap \mathrm{ma} / \mathrm{kn}$ colennmathinnine in broiler breeder diets results in higher serum and tissue Se Loading [MathJax]/jax/output/CommonHTML/jax.js

Page $17 / 30$ 
deposition than other sources of Se (Li et al. 2018). Also, Han et al. (2017) reported a higher Se concentration from different Se sources in serum and organs of layers fed $0.3 \mathrm{mg} / \mathrm{kg} \mathrm{Se}$. Moreover, layer chicks fed a $0.3 \mathrm{mg} / \mathrm{kg}$ diet of both nano-Se and sodium selenite showed a significant increase in Se concentrations in tissues, organs, and serum (Mohapatra et al., 2014). Because SeMet is available in an organic form of Se and is closely linked to its bioavailability and assimilation (Briens et al. 2013; Mohapatra et al., 2014), the present findings are justified.

The significant differences found between the treatment groups in serum and breast tissue may be due to dissimilar metabolic pathways, as Se can be incorporated into selenoprotein as selenocysteine from inorganic and organic sources, while SeMet is incorporated in a nonspecific direction as methionine (Surai and Kochish 2019). Inorganic Se compounds are mainly used to synthesize selenoproteins and not replenish Se deposits in tissues in the Se metabolism pathway (Moslehi et al. 2019). The addition of organic Se (Se-yeast or SeMet) into the diet is connected with a significant increase of Se level in laying hens tissue (Invernizzi et al. 2013; Jing et al. 2015). Therefore, the quantity of Se uptake and its absorption in egg, tissue, and blood of laying hens is determined by the Se chemical form in organic sources (Jing et al. 2015). However, more research is required to explore the complete metabolic pathway of organic (Se-yeast or ADS18) sources.

\section{Conclusion}

In conclusion, dietary Se supplementation, particularly organic forms (ADS18 or Se-Yeast), enhances hen serum and hepatic antioxidant enzyme activity while lowering total serum cholesterol and serum triglycerides concentrations. Moreover, hens given dietary Se treatments exhibited greater selenium concentration in their egg yolks, serum, and breast tissue. In comparison to inorganic (sodium selenite) $\mathrm{Se}, 0.3 \mathrm{mg} / \mathrm{kg}$ of enriched bacterial protein from ADS18 Se improves antioxidant enzymes activity, serum biochemical parameters, and Se concentrations in laying hens, making it a significant alternative source of Se.

\section{Declarations}

\section{Authors' contributions}

A.I.M designed and conduct the animal experiments and all the laboratory analyses, analyzed and interpreted data, and drafted the manuscript. A.A.S. designed, supervised, and administrated the overall research project, A.M.D, T.C.L, and H. A participated in the whole preparation of the manuscript. All authors read and approved the final manuscript.

\section{Acknowledgments}

A.I. was a recipient of a scholarship from Tertiary Education Trust Funds (TETFund) and Federal University Dutse, Jigawa State Nigeria. 


\section{Data availability}

Not applicable.

\section{Code availability}

Not applicable.

\section{Ethics approval}

All experiential steps were implemented according to the Local Experimental Animal Care Panel and permitted by the Institutional Animal Care and Use Committee of University Putra Malaysia (UPM/IACUC/AUP-R063/2018).

\section{Funding}

This study was financed by the Fundamental Research Grant Scheme (FRGS 5524272) granted by the Malaysian Ministry of Higher Education.

\section{Competing interests}

The authors declare that they have no competing interests.

\section{Consent to participate}

Not applicable.

\section{Consent to publish}

All authors give consent for publication.

\section{References}

1. Abd El-Hack ME, Mahrose K, Askar AA, et al (2017) Single and combined impacts of vitamin a and selenium in diet on productive performance, egg quality, and some blood parameters of laying hens during hot season. Biol Trace Elem Res 177:169-179. https://doi.org/10.1007/s12011-016-0862-5

2. Abdel-Azeem NM, Abdel-Rahman SM, Amin HF, et al (2019) Effect of dietary organic selenium supplementation on growth performance, carcass characteristics and antioxidative status of growing rabbits. J World's Poult Res 9:16-25. https://doi.org/10.36380/scil.2019.wvj3

3. Abdel-Daim MM, Dawood MAO, Aleya L, Alkahtani S (2020) Effects of fucoidan on the hematic indicators and antioxidative responses of Nile tilapia (Oreochromis niloticus) fed diets contaminated with aflatoxin B1. Environ Sci Pollut Res 27:12579-12586. https://doi.org/10.1007/s11356-02007854-w 
4. Ahmadi M, Ahmadian A, Seidavi AR (2018) Effect of different levels of nano-selenium on performance, blood parameters, immunity and carcass characteristics of broiler chickens. Poult Sci J 6:99-108. https://doi.org/10.22069/psj.2018.13815.1276

5. Aksoz E, Korkut $O$, Aksit D, Gokbulut C (2020) Vitamin E ( $a$-, $\beta+\gamma$ - and $\delta$-tocopherol) levels in plant oils. Flavour Fragr J 35:504-510. https://doi.org/10.1002/ffj.3585

6. Alimohamady R, Aliarabi H, Bahari A, Dezfoulian AH (2013) Influence of different amounts and sources of selenium supplementation on performance, some blood parameters, and nutrient digestibility in lambs. Biol Trace Elem Res 154:45-54. https://doi.org/10.1007/s12011-013-9698-4

7. Amer SA, Omar AE, Abd El-Hack ME (2018) Effects of selenium- and chromium-enriched diets on growth performance, lipid profile, and mineral concentration in different tissues of growing rabbits. Biol Trace Elem Res 187:92-99. https://doi.org/10.1007/s12011-018-1356-4

8. Ayyat MS, Al-Sagheer AA, Abd El-Latif KM, Khalil BA (2018) Organic selenium, probiotics, and prebiotics effects on growth, blood biochemistry, and carcass traits of growing rabbits during summer and winter seasons. Biol Trace Elem Res 186:162-173. https://doi.org/10.1007/s12011018-1293-2

9. Aziz, M. A., Diab, A. S., \& Mohammed AA (2019) Antioxidant categories and mode of action. In: Shalaby E (ed) Antioxidants, IntechOpen. IntechOpen, London, United Kingdom, London, United Kingdom, pp 3-22

10. Behne, D. and Kyriakopoulos A (2001) Mammalian selenium-containing proteins. Annu RevNutr 21:453-73

11. Biswas, A., Ahmed, M., Bharti, V. K., \& Singh SB (2011) Effect of antioxidants on physio-biochemical and hematological parameters in broiler chicken at high altitude. Asian-Australasian J Anim Sci 24:246-249. https://doi.org/10.5713/ajas.2011.10060

12. Boiago MM, Borba $H$, Leonel FR, et al (2014) Sources and levels of selenium on breast meat quality of broilers. Ciência Rural 44:1692-1698. https://doi.org/10.1590/0103-8478cr20131256

13. Briens M, Mercier Y, Rouffineau F, et al (2013) Comparative study of a new organic selenium source vs. seleno-yeast and mineral selenium sources on muscle selenium enrichment and selenium digestibility in broiler chickens. Br J Nutr 110:617-624. https://doi.org/10.1017/S0007114512005545

14. Canoğullari S, Ayaşan T, Baylan M, Çopur G (2010) The effect of organic and inorganic selenium supplementation on egg production parameters and egg selenium content of laying Japanese quail. Kafkas Univ Vet Fak Derg 16:743-749. https://doi.org/10.9775/kvfd.2009.1560

15. Çelebi Ş (2019) Effect of dietary vitamin e, selenium and their combination on concentration of selenium, MDA, and antioxidant enzyme activities in some tissues of laying hens. Pak J Zool 51:1155-1161. https://doi.org/10.17582/journal.pjz/2019.51.3.1155.1161

16. Chantiratikul A, Chinrasri O, Chantiratikul P (2008) Effect of sodium selenite and zinc- Iselenomethionine on performance and selenium concentrations in eggs of laying hens. Asian tps://doi.org/https://doi.org/10.5713/ajas.2008.70576 
17. Chen G, Wu J, Li C (2013) The effect of different selenium levels on production performance and biochemical parameters of broilers. Ital J Anim Sci 12:486-491.

https://doi.org/10.4081/ijas.2013.e79

18. Chiaiese P, Corrado G, Minutolo M, et al (2019) Transcriptional regulation of ascorbic acid during fruit ripening in pepper (Capsicum annuum) varieties with low and high antioxidants content. Plants 8:112. https://doi.org/10.3390/plants8070206

19. Cimrin T, Tunca Rl, Avsaroglu MD, et al (2020) Effects of an antibiotic and two phytogenic substances (cinnamaldehyde and 1,8-cineole) on yolk fatty acid profile and storage periodassociated egg lipid peroxidation level. Rev Bras Zootec 49:1-10. https://doi.org/10.37496/rbz4920190270

20. Čobanová K, Petrovič V, Mellen M, et al (2011) Effects of dietary form of selenium on its distribution in eggs. Biol Trace Elem Res 144:736-746. https://doi.org/10.1007/s12011-011-9125-7

21. Dalia, A. M., Loh, T. C., Sazili, A. Q., Jahromi, M. F., \& Samsudin AA (2017) The effect of dietary bacterial organic selenium on growth performance, antioxidant capacity, and Selenoproteins gene expression in broiler chickens. BMC Vet Res 13:254. https://doi.org/10.1186/s12917-017-1159-4

22. Dalia AM, Loh TC, Sazili AQ, et al (2018) Effects of vitamin E, inorganic selenium, bacterial organic selenium, and their combinations on immunity response in broiler chickens. BMC Vet Res 14:1-10. https://doi.org/10.1186/s12917-018-1578-x

23. Dalia AM, Loh TC, Sazili AQ, et al (2017) Characterization and Identification of Organic Seleniumenriched Bacteria Isolated from Rumen Fluid and Hot Spring Water. Microbiol Biotechnol Lett 45:343-353

24. Delezie E, Rovers $M$, Van Der Aa A, et al (2014) Comparing responses to different selenium sources and dosages in laying hens. Poult Sci 93:3083-3090. https://doi.org/10.3382/ps.2014-04301

25. Dhingra S, Bansal MP (2006) Attenuation of LDL receptor gene expression by selenium deficiency during hypercholesterolemia. Mol Cell Biochem 282:75-82. https://doi.org/10.1007/s11010-0061266-1

26. Eşrefoğlu M (2009) Cell injury and death: Oxidative stress and antioxidant defense system: Review. Turkiye Klin J Med Sci 29:1660-1676

27. Fernández-Lázaro, D., Fernandez-Lazaro, C. I., Mielgo-Ayuso, J., Navascués, L. J., Córdova Martínez, A., \& Seco-Calvo J (2020) The role of selenium mineral trace element in exercise: antioxidant defense system, muscle performance, hormone response, and athletic performance. A Systematic Review. Nutrients 12:1790

28. Giuffrè AM (2019) Bergamot (Citrus bergamia, Risso): The effects of cultivar and harvest date on functional properties of juice and cloudy juice. Antioxidants 8:221. https://doi.org/10.3390/antiox8070221

29. Gouta H, Laaribi I, Ksia E, et al (2021) Physical properties, biochemical and antioxidant contents of new promising Tunisian almond genotypes: Traits stability, quality aspects and post-harvest 
30. Halliwell B (1990) How to characterize a biological antioxidant. Free Radic Res Commun 9:1-32

31. Han XJ, Qin P, Li WX, et al (2017) Effect of sodium selenite and selenium yeast on performance, egg quality, antioxidant capacity, and selenium deposition of laying hens. Poult Sci 96:3973-3980. https://doi.org/10.3382/ps/pex216

32. Hossein Zadeh M, Kermanshahi H, Sanjabi MR, et al (2018) Comparison of different selenium sources on performance, serum attributes and cellular immunity in broiler chickens. Poult Sci J 6:191-203. https://doi.org/10.22069/psj.2018.15232.1341

33. Hozzein WN, Saleh AM, Habeeb $\mathrm{TH}$, et al (2020) $\mathrm{CO}_{2}$ treatment improves the hypocholesterolemic and antioxidant properties of fenugreek seeds. Food Chem 308:125661. https://doi.org/10.1016/j.foodchem.2019.125661

34. Huang D, Boxin OU, Prior RL (2005) The chemistry behind antioxidant capacity assays. J Agric Food Chem 53:1841-1856. https://doi.org/10.1021/jf030723c

35. Huma N, Sajid A, Khalid A, Wardah H, Moazama B, Shakeela P, Sadia M SM (2019) Toxic effect of insecticides mixtures on antioxidant enzymes in different organs of fish, Labeo rohita. Pak J Zool 51:1355-1361. https://doi.org/10.17582/journal.pjz/2019.51.4.1355.1361

36. Humam AM, Loh TC, Foo HL, et al (2021) Supplementation of postbiotic RI11 improves antioxidant enzyme activity, upregulated gut barrier genes, and reduced cytokine, acute phase protein, and heat shock protein 70 gene expression levels in heat-stressed broilers. Poult Sci. https://doi.org/10.1016/j.psj.2020.12.011

37. Invernizzi G, Agazzi A, Ferroni M, et al (2013) Effects of inclusion of selenium-enriched yeast in the diet of laying hens on performance, eggshell quality, and selenium tissue deposition. Ital J Anim Sci 12:1-8. https://doi.org/10.4081/ijas.2013.e1

38. Jagtap R, Maher W (2016) Determination of selenium species in biota with an emphasis on animal tissues by HPLC - ICP-MS. Microchem J 124:422-529.

https://doi.org/10.1016/j.microc.2015.07.014

39. Jegede A V., Oduguwa OO, Oso AO, et al (2012) Growth performance, blood characteristics and plasma lipids of growing pullet fed dietary concentrations of organic and inorganic copper sources. Livest Sci 145:298-302. https://doi.org/10.1016/j.livsci.2012.02.011

40. Jeyanthi GK and GP (2010) The effect of supplementation of diet with vitamin-e and selenium and their combinations on the performance and lipid profiles of layer chickens. Int J Pharma Bio Sci 1:111

41. Jing CL, Dong XF, Wang ZM, et al (2015) Comparative study of DL-selenomethionine vs sodium selenite and seleno-yeast on antioxidant activity and selenium status in laying hens. Poult Sci 94:965-975. https://doi.org/10.3382/ps/pev045

42. Kim, S., Chao, P. Y., \& Allen KG (1992) Inhibition of elevated hepatic glutathione abolishes copper deficiency cholesterolemia. FASEB J 6:2467-2471.

43. Konjufca VH, Pesti GM, Bakalli RI (1997) Modulation of Cholesterol Levels in Broiler Meat by Dietary Loading [MathJax]/jax/output/CommonHTML/jax.js 271. https://doi.org/10.1093/ps/76.9.1264 
44. Kumar N, Garg AK, Mudgal V, et al (2008) Effect of different levels of selenium supplementation on growth rate, nutrient utilization, blood metabolic profile, and immune response in Lambs. Biol Trace Elem Res 126:44-56. https://doi.org/10.1007/s12011-008-8214-8

45. Kurutas EB (2016) The importance of antioxidants which play the role in cellular response against oxidative / nitrosative stress: current state. Nutr J 15:1-22. https://doi.org/10.1186/s12937-0160186-5

46. Labunskyy VM, Hatfield DL, Gladyshev VN (2014) Selenoproteins: Molecular pathways and physiological roles. Physiol Rev 94:739-777. https://doi.org/10.1152/physrev.00039.2013

47. Li JL, Zhang L, Yang ZY, et al (2017) Effects of different selenium sources on growth performance, antioxidant capacity and meat quality of local chinese subei chickens. Biol Trace Elem Res 181:340346. https://doi.org/10.1007/s12011-017-1049-4

48. Li KX, Wang JS, Yuan D, et al (2018) Effects of different selenium sources and levels on antioxidant status in broiler breeders. Asian-Australasian J Anim Sci 31:1939-1945.

https://doi.org/10.5713/ajas.18.0226

49. Lipiec E, Siara G, Bierla K, et al (2010) Determination of selenomethionine, selenocysteine, and inorganic selenium in eggs by HPLC-inductively coupled plasma mass spectrometry. Anal Bioanal Chem 397:731-741. https://doi.org/10.1007/s00216-010-3544-8

50. Liu H, Yu Q, Fang C, et al (2020a) Effect of selenium source and level on performance, egg quality, egg selenium content, and serum biochemical parameters in laying hens. Foods 9:68. https://doi.org/10.3390/foods 9010068

51. Liu H, Yu Q, Tang X, et al (2020b) Effect of selenium on performance, egg quality, egg selenium content and serum antioxidant capacity in laying hens. Pakistan J Zool 52:635-640

52. Liu H, Yu Q, Tang X, et al (2020c) Effect of selenium on performance, egg quality, egg selenium content and serum antioxidant capacity in laying hens. Pakistan J Zool 52:635-640. https://doi.org/10.17582/journal.pjz/20190424040448

53. Lu J, Qu L, Ma M, et al (2020) Efficacy evaluation of selenium-enriched yeast in laying hens: effects on performance, egg quality, organ development, and selenium deposition. Poult Sci 99:6267-6277. https://doi.org/10.1016/j.psj.2020.07.041

54. Lu J, Qu L, Shen MM, et al (2019) Effects of high-dose selenium-enriched yeast on laying performance, egg quality, clinical blood parameters, organ development, and selenium deposition in laying hens. Poult Sci 98:2522-2530. https://doi.org/10.3382/ps/pey597

55. Lv L, Li L, Zhang R, et al (2019) Effects of dietary supplementation of selenium enriched yeast on egg selenium content and egg production of North China hens. Pak J Zool 51:49-55. https://doi.org/10.17582/journal.pjz/2019.51.1.49.55

56. Lohmann Brown-Classic Management Guide, Lohmann Tierzucht Lohmann(2018)

57. Mahan DC, Kim YY (1996) Effect of inorganic or organic selenium at two dietary levels on reproductive performance and tissue selenium concentrations in first-parity gilts and their progeny. $J$ 
58. Mahan DC, Parrett NA (1996) Evaluating the efficacy of selenium-enriched yeast and sodium selenite on tissue selenium retention and serum glutathione peroxidase activity in grower and finisher swine. J Anim Sci 2967-2974

59. Mahima, Amit Kumar Verma, Amit Kumar, Anu Rahal VK and DR (2012) Inorganic versus organic selenium supplementation: A review. Pakistan J Biol Sci 15:418-425. https://doi.org/10.3923/pjbs.2012.418.425

60. Malaysia S (2009) Halal Food-Production, Preparation, Handling and Storage-General Guidelines (Second Revision)

61. Mangiapane E, Pessione A, Pessione E (2014) Selenium and selenoproteins: An overview on different biological systems. Curr Protein Pept Sci 15:598-607.

https://doi.org/10.2174/1389203715666140608151134

62. Markovic R, Ciric J, Starcevic M, et al (2018) Effects of selenium source and level in diet on glutathione peroxidase activity, tissue selenium distribution, and growth performance in poultry. Anim Heal Res Rev 19:166-176. https://doi.org/10.1017/S1466252318000105

63. Meng T, Liu Y lin, Xie C yan, et al (2019) Effects of different selenium sources on laying performance, egg selenium concentration, and antioxidant capacity in laying hens. Biol Trace Elem Res 189:548555. https://doi.org/10.1007/s12011-018-1490-z

64. Meng TT, Lin X, Xie CY, et al (2020) Nanoselenium and selenium yeast have minimal differences on egg production and se deposition in laying hens. Biol Trace Elem Res 1-8. https://doi.org/10.1007/s12011-020-02349-8

65. Mengistu BM, Bitsue HK, Huang K (2020) The Effects of selenium-enriched probiotics on growth performance, oocysts shedding, intestinal cecal lesion scores, antioxidant capacity, and mrna gene expression in chickens infected with Eimeria tenella. Biol Trace Elem Res 1-14. https://doi.org/10.1007/s12011-020-02118-7

66. Meyers $L$ (2000) Establishment of dietary reference intakes for dietary antioxidants

67. Mohamed DA, Sazili AQ, Chwen LT, Samsudin AA (2020) Effect of microbiota-selenoprotein on meat selenium content and meat quality of broiler chickens. Animals 10:1-11. https://doi.org/10.3390/ani10060981

68. Mohapatra, P., Swain, R. K., Mishra, S. K., Behera, T., Swain, P., Mishra, S. S., Behura, N. C., Sabat, S. C., Sethy, K., Dhama, K. and Jayasankar P (2014) Effects of dietary nano-selenium on tissue selenium deposition, antioxidant status and immune functions in layer chicks. Int J Pharmacol 10:160-167. https://doi.org/10.3923/ijp.2014.160.167

69. Mohapatra P, Swain RK, Mishra SK, et al (2014) Effects of dietary nano-selenium supplementation on the performance of layer grower birds. Asian J. Anim. Vet. Adv. 9:641-652

70. Moslehi H, Navidshad B, Sharifi SD, Aghjegheshlagh FM (2019) Effects of selenium and flaxseed on selenium content and antioxidant properties of eggs and immune response in hens. South African $\mathrm{J}$ Anim Sci 49:770-780. https://doi.org/10.4314/sajas.v49i4.19 
71. Mu Y, Zhang K, Bai S, et al (2019) Effects of vitamin E supplementation on performance, serum biochemical parameters and fatty acid composition of egg yolk in laying hens fed a diet containing ageing corn. J Anim Physiol Anim Nutr (Berl) 103:135-145. https://doi.org/10.1111/jpn.13017

72. Muhammad, A. I., Mohamed, D. A. A., Chwen, L. T., Akit, H. and Samsudin AA (2021) Effect of sodium selenite, selenium yeast, and bacterial protein on chicken egg yolk color, antioxidant profiles, and oxidative stability. Foods 10:1-20. https://doi.org/10.3390/foods 10040871

73. Nabi F, Arain MA, Hassan F, et al (2020) Nutraceutical role of selenium nanoparticles in poultry nutrition: a review. World's Poult Sci J 00:1-13. https://doi.org/10.1080/00439339.2020.1789535

74. Nandi A, Yan LJ, Jana CK, Das N (2019) Role of catalase in oxidative stress- and age-associated degenerative diseases. Oxid Med Cell Longev 2019:. https://doi.org/10.1155/2019/9613090

75. Nasiri K, Kazemi-Fard M, Rezaei M, Yousefi S (2019) Supplementation of sodium selenite and methionine on concentration of selenium in egg and serum, antioxidant enzymes activity and immune response of iranian native broiler breeders. Poult Sci J 7:119-129. https://doi.org/10.22069/psj.2019.16438.1427

76. NRC (1994) Nutrient Requirements of Poultry. Ninth Revised Edition, 1994. Washington, DC: The National Academies Press.

77. Okado-Matsumoto A, Fridovich I (2001) Subcellular distribution of superoxide dismutases (SOD) in rat liver. J Biol Chem 276:38388-38393. https://doi.org/10.1074/jbc.M105395200

78. Okunlola D., AkandeT.O, Nuga H. (2015) Haematological and serum characteristics of broiler birds fed diets supplemented with varying levels of selenium powder. J Biol Agric Healthc 5:107-111

79. Paiva FA, Netto AS, Corrêa LB, et al (2019) Organic selenium supplementation increases muscle selenium content in growing lambs compared to inorganic source. Small Rumin Res 175:57-64. https://doi.org/10.1016/j.smallrumres.2019.04.008

80. Pan C, Huang K, Zhao Y, et al (2007) Effect of selenium source and level in hen's diet on tissue selenium deposition and egg selenium concentrations. J Agric Food Chem 55:1027-1032. https://doi.org/10.1021/jf062010a

81. Pan C, Zhao Y, Liao SF, et al (2011) Effect of selenium-enriched probiotics on laying performance, egg quality, egg selenium content, and egg glutathione peroxidase activity. J Agric Food Chem 59:11424-11431. https://doi.org/10.1021/jf202014k

82. Payne RL, Southern LL (2005) Comparison of inorganic and organic selenium sources for broilers. Poult Sci 84:898-902. https://doi.org/10.1093/ps/84.6.898

83. Perić L, Milošević N, Žikić D, et al (2009) Effect of selenium sources on performance and meat characteristics of broiler chickens. J Appl Poult Res 18:403-409. https://doi.org/10.3382/japr.200800017

84. Reda FM, Swelum AA, Hussein EOS, Elnesr SS (2020) Effects of varying dietary dl-methionine levels on productive and reproductive performance, egg quality, and blood biochemical parameters of quail breeders. Animals 10:1-12 
85. Revilla E, Maria CS, Miramontes E, et al (2009) Nutraceutical composition, antioxidant activity and hypocholesterolemic effect of a water-soluble enzymatic extract from rice bran. Food Res Int 42:387-393. https://doi.org/10.1016/j.foodres.2009.01.010

86. Rotruck, J. T., Pope, A. L., Ganther, H. E., Swanson, A. B., Hafeman, D. G., \& Hoekstra W (1973) Selenium: Biochemical role as a component of glutathione peroxidase. Science (80- ) 179:588-590. https://doi.org/10.1126/science.179.4073.588

87. Salehi B, Martorell M, Arbiser JL, et al (2018) Antioxidants: Positive or negative actors? Biomolecules 8:1-11. https://doi.org/10.3390/biom8040124

88. Saracila M, Panaite T, Tabuc C, et al (2020) Dietary ascorbic acid and chromium supplementation for broilers reared under thermoneutral conditions vs. high heat stress. Lucr Științifice-Universitatea Științe Agric şi Med Vet Ser Zooteh 73:41-47

89. Sethy K, Dass RS, Garg AK, et al (2015) Effect of different selenium sources (Selenium yeast and Sodium selenite) on haematology, blood chemistry and thyroid hormones in male goats (Capra hircus). Indian J Anim Res 49:788-792. https://doi.org/10.18805/ijar.7040

90. Sheiha AM, Abdelnour SA, Abd El-Hack ME, et al (2020) Effects of dietary biological or chemicalsynthesized nano-selenium supplementation on growing rabbits exposed to thermal stress. Animals 10:1-16. https://doi.org/10.3390/ani10030430

91. Sheoran N (2017) Organic Minerals in Poultry. Adv Res 12:1-10. https://doi.org/10.9734/AIR/2017/37878

92. Shi L, Ren Y, Zhang C, et al (2018) Effects of organic selenium (Se-enriched yeast) supplementation in gestation diet on antioxidant status, hormone profile and haemato-biochemical parameters in Taihang Black Goats. Anim Feed Sci Technol 238:57-65. https://doi.org/10.1016/j.anifeedsci.2018.02.004

93. Sizova E, Miroshnikov S, Ayasan T (2021) Efficiency and safety of using different sources of zinc in poultry nutrition. IOP Conf Ser Earth Environ Sci 624:012043. https://doi.org/10.1088/1755$1315 / 624 / 1 / 012043$

94. Skřivan M, Šimáně J, Dlouhá G, Doucha J (2006) Effect of dietary sodium selenite, Se-enriched yeast and Se-enriched Chlorella on egg Se concentration, physical parameters of eggs and laying hen production. Czech J Anim Sci 51:163-167. https://doi.org/10.17221/3924-cjas

95. Sugiharto S (2019) A review of filamentous fungi in broiler production. Ann Agric Sci 64:1-8. https://doi.org/10.1016/j.aoas.2019.05.005

96. Sun X, Yue S, Qiao Y, et al (2020) Dietary supplementation with Selenium-enriched earthworm powder improves anti-oxidative ability and immunity of laying hens. Poult Sci 99:5344-5349. https://doi.org/10.1016/j.psj.2020.07.030

97. Sunde RA, Li JL, Taylor RM (2016) Insights for setting of nutrient requirements, gleaned by comparison of selenium status biomarkers in Turkeys and chickens versus rats, mice, and lambs. Adv Nutr 7:1129-1138. https://doi.org/10.3945/an.116.012872 
98. Surai, P. F. and Dvorska JE (2002) Strategies to enhance antioxidant protection and implications for the wellbeing of companion animals. In: Jacques TL and K (ed) Nutritional biotechnology in the feed and food industries. Proceedings of Alltech's Eighteenth Annual Symposium Edited, Nottingham University Press Manor Farm, Church Lane, Thrumpton Nottingham, NG11 OAX, United Kingdom, $p$ 504

99. Surai PF (2006) Selenium in Nutrition and Health, First publ. Nottingham University Press Manor Farm, Main Street, Thrumpton Nottingham NG11 OAX, United Kingdom, United Kingdom

100. Surai PF (2002) Selenium. In: Surai PF (ed) Natural Antioxidants in Avian Nutrition and Reproduction, First. Nottingham University Press, Nottingham University, UK Manor Farm, Main Street, Thrumpton Nottingham, NG11 OAX, United Kingdom, pp 233-283

101. Surai PF, Kochish II (2019) Nutritional modulation of the antioxidant capacities in poultry: The case of selenium. Poult Sci 98:4231-4239. https://doi.org/10.3382/ps/pey406

102. TIMUR C, UTLU N (2020) Influence of vitamin E and organic selenium supplementation on antioxidant enzymes activities in blood and egg samples of laying hens. J Inst Sci Technol 10:694701. https://doi.org/10.21597/jist.544969

103. Tufarelli V, Ceci E, Laudadio V (2016) 2-Hydroxy-4-Methylselenobutanoic acid as new organic selenium dietary supplement to produce selenium-enriched eggs. Biol Trace Elem Res 171:453-458. https://doi.org/10.1007/s12011-015-0548-4

104. Urbankova L, Skalickova S, Pribilova M, et al (2021) Effects of sub-lethal doses of selenium nanoparticles on the health status of rats. Toxics 9:28. https://doi.org/10.3390/toxics 9020028

105. Utterback PL, Parsons CM, Yoon I, Butler J (2005) Effect of supplementing selenium yeast in diets of laying hens on egg selenium content. Poult Sci 84:1900-1901. https://doi.org/10.1093/ps/84.12.1900

106. Wang G, Liu LJ, Tao WJ, et al (2019) Effects of replacing inorganic trace minerals with organic trace minerals on the production performance, blood profiles, and antioxidant status of broiler breeders. Poult Sci 98:2888-2895. https://doi.org/10.3382/ps/pez035

107. Wrobel JK, Power R, Toborek M (2016) Biological activity of selenium: Revisited. IUBMB Life 68:97105. https://doi.org/10.1002/iub.1466

108. Xia WG, Chen W, Abouelezz KFM, et al (2020) The effects of dietary Se on productive and reproductive performance, tibial quality, and antioxidant capacity in laying duck breeders. Poult Sci 99:3971-3978. https://doi.org/10.1016/j.psj.2020.04.006

109. Xu XR, Yu HT, Yang Y, et al (2016) Quercetin phospholipid complex significantly protects against oxidative injury in ARPE-19 cells associated with activation of Nrf2 pathway. Eur J Pharmacol 770:1-8. https://doi.org/10.1016/j.ejphar.2015.11.050

110. Yang KC, Lee LT, Lee YS, et al (2010) Serum selenium concentration is associated with metabolic factors in the elderly: A cross-sectional study. Nutr Metab 7:20-22. https://doi.org/10.1186/17437075-7-38 
111. Yang L, Tu D, Wang N, et al (2019) The protective effects of DL-Selenomethionine against T-2/HT-2 toxins-induced cytotoxicity and oxidative stress in broiler hepatocytes. Toxicol Vitr 54:137-146. https://doi.org/10.1016/j.tiv.2018.09.016

112. Yuan D, Zhan XA, Wang YX (2012) Effect of selenium sources on the expression of cellular glutathione peroxidase and cytoplasmic thioredoxin reductase in the liver and kidney of broiler breeders and their offspring. Poult Sci 91:936-942. https://doi.org/10.3382/ps.2011-01921

113. Zhang Q, Chen L, Guo K, et al (2013) Effects of different selenium levels on gene expression of a subset of selenoproteins and antioxidative capacity in mice. Biol Trace Elem Res 154:255-261. https://doi.org/10.1007/s12011-013-9710-z

114. Zhang R, Liu Y, Xing L, et al (2018) The protective role of selenium against cadmium-induced hepatotoxicity in laying hens: Expression of HSPS and inflammation-related genes and modulation of elements homeostasis. Ecotoxicol Environ Saf 159:205-212. https://doi.org/10.1016/j.ecoenv.2018.05.016

115. Zhang X, Tian L, Zhai S, et al (2020) Effects of selenium-enriched yeast on performance, egg quality, antioxidant balance, and egg selenium content in laying ducks. Front Vet Sci 7:1-10. https://doi.org/10.3389/fvets.2020.00591

116. Zhang Y, Zhu S, Wang X, et al (2011) The effect of dietary selenium levels on growth performance, antioxidant capacity and glutathione peroxidase 1 (GSHPx1) mRNA expression in growing meat rabbits. Anim Feed Sci Technol 169:259-264. https://doi.org/10.1016/j.anifeedsci.2011.07.006

117. Zhou W, Miao S, Zhu M, et al (2021) Effect of sns. Biol Trace Elem Res. https://doi.org/10.1007/s12011-020-02532-x

\section{Figures}




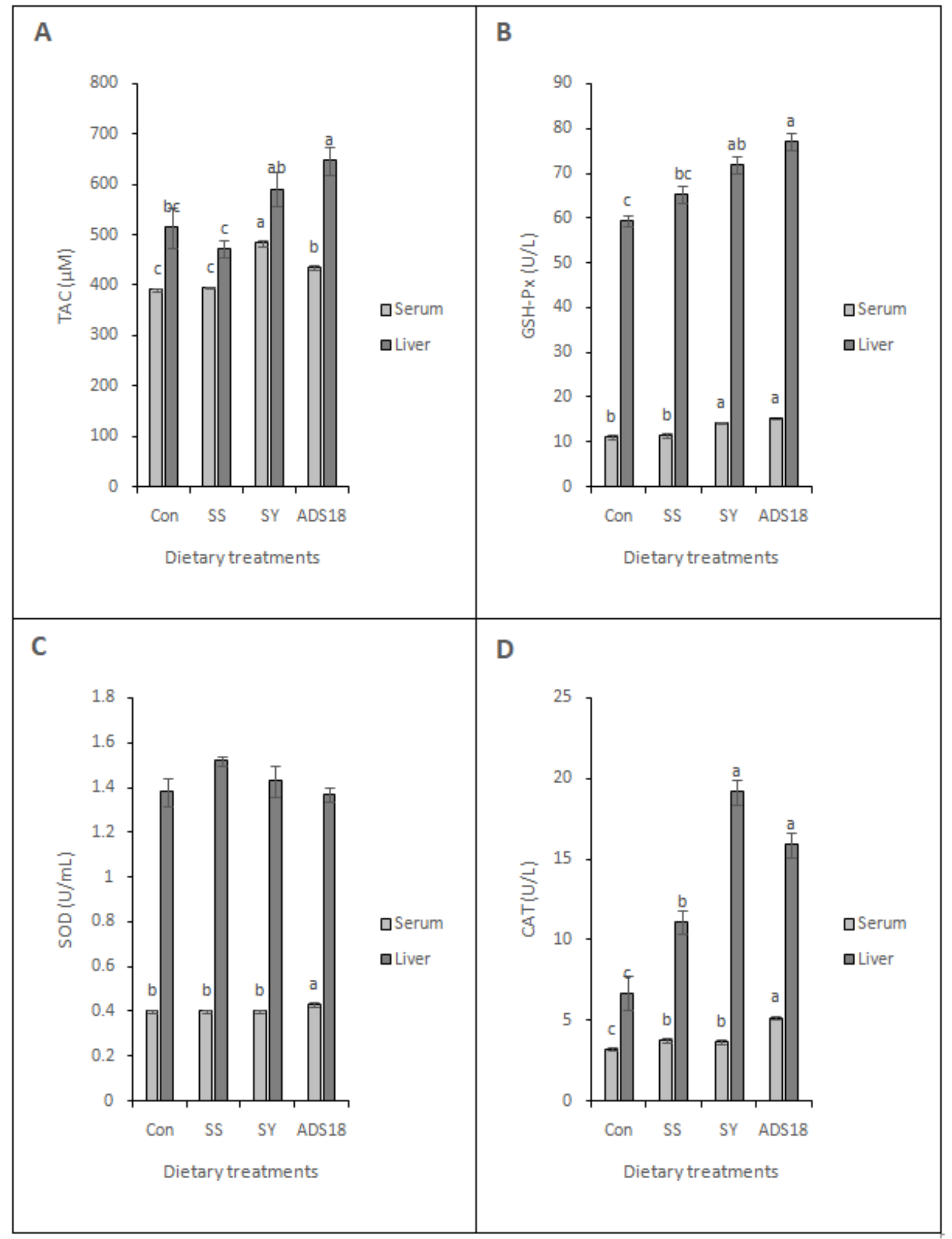

Figure 1

Serum and hepatic antioxidant enzyme activities in laying hens fed different dietary selenium sources. ${ }^{*}$ Con = Control, $S S$ = Sodium selenite; $S Y=$ Selenium yeast; ADS18 = Bacterial enriched organic Se a $-\mathrm{c}$ Values within the same column with different superscript letters differ $(P<0.05)$. TAC expressed as $\mu \mathrm{M}$ Trolox Equivalents. Glutathione peroxidase activity is expressed as $\mathrm{U} / \mathrm{L}$ (one unit is the amount of GSHLoading [MathJax]/jax/output/CommonHTML/jax.js ). SOD one unit corresponds to the amount of enzyme needed 
to scavenges the dismutation of the superoxide radical. CAT activity is expressed as $\mathrm{U} / \mathrm{L}$ (one unit is the amount of CAT that decomposes $1 \mu$ mole of $\mathrm{H} 2 \mathrm{O} 2$ per min).

a

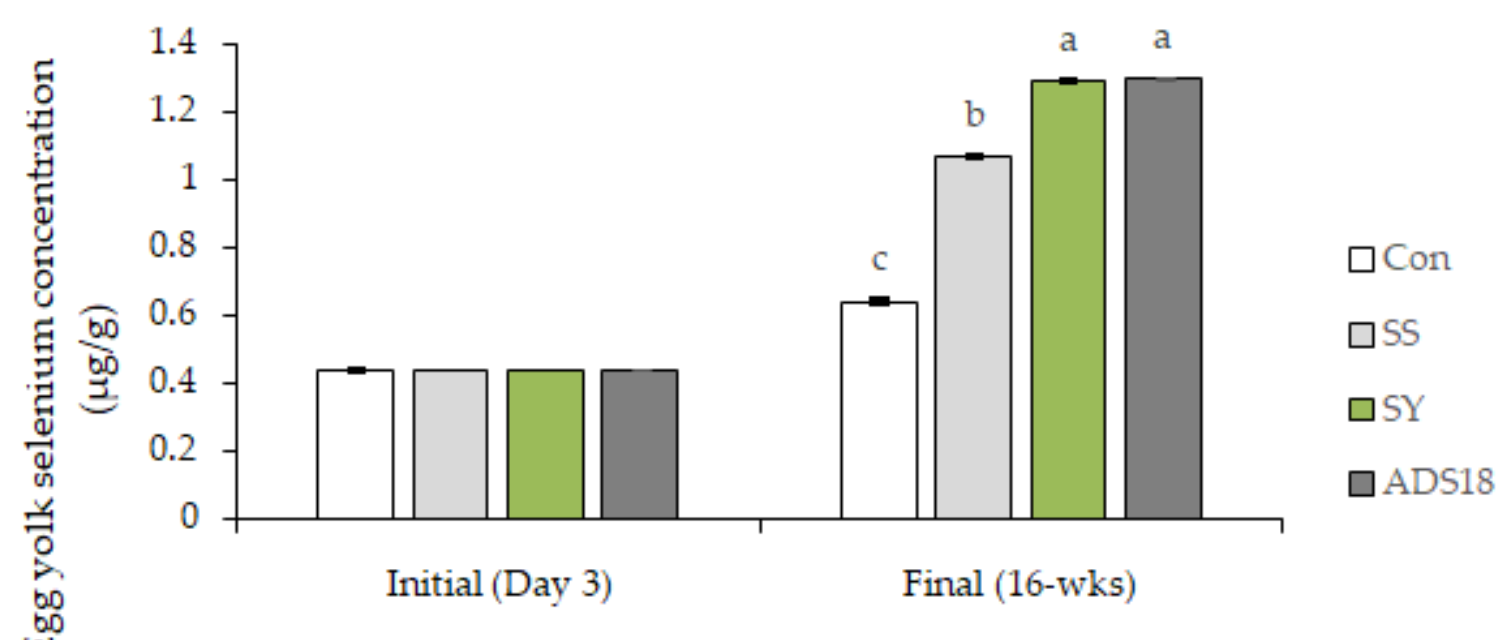

Egg yolks (freeze dried-basis)

b

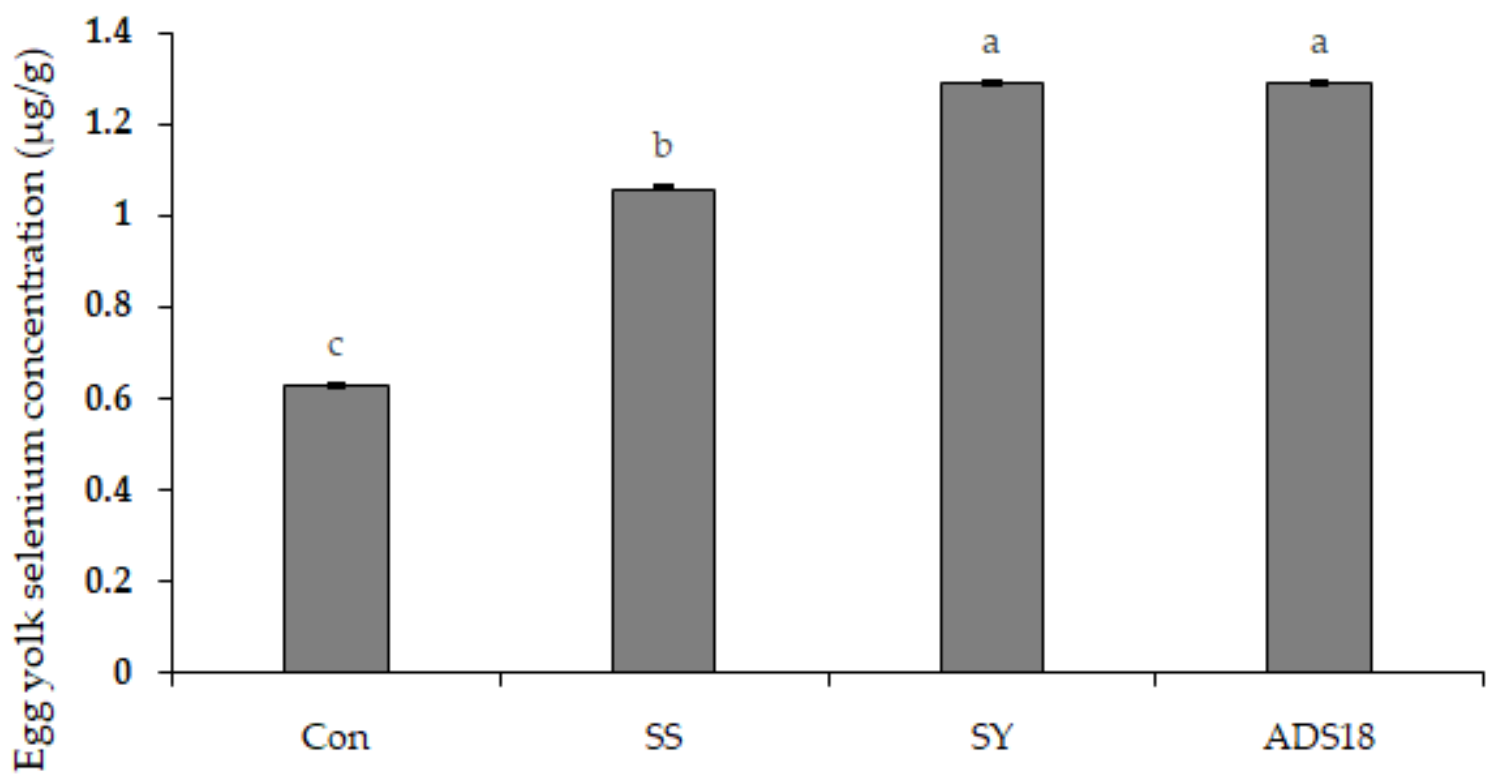

Stored egg yolks (freeze dried-basis) at $4 \pm 2{ }^{\circ} \mathrm{C}$ for 14-days

\section{Figure 2}

Egg yolk Se concentration ( $\mu \mathrm{g} / \mathrm{g}$ freeze-dried basis). a. Egg yolk Se concentrations of hens at initial (3-d) and final (16 wks). b. Egg yolk Se concentrations of post stored (14-days at $4 \pm 2{ }^{\circ} \mathrm{C}$ ) eggs at 18 wks. Experimental diets: Con $=$ control, $S S=$ Sodium selenite SY $=$ Selenium yeast $; A D S 18=$ Bacterial enriched organic Se. Bars with different superscripts $(a, b, c)$ are significantly different at $\mathrm{P}<0.05$. Egg yolk samples were initial, final (16 wks), and stored (18 wks) at $4 \pm 2{ }^{\circ} \mathrm{C}$ for 14 days. Data are means of 6 Loading [MathJax]/jax/output/CommonHTML/jax.js sample). 